Article

\title{
Understanding the Importance of Front Yard Accessibility for Community Building: A Case Study of Subiaco, Western Australia
}

\author{
Abu Yousuf Swapan ${ }^{1, *(D)}$, Dora Marinova ${ }^{1}$ (D) and Joo Hwa Bay ${ }^{2}$ \\ 1 Curtin University Sustainability Policy Institute, Curtin University, Building 209, Bentley, \\ Perth, WA 6102, Australia; d.marinova@curtin.edu.au \\ 2 School of Design and the Built Environment, Curtin University, Bentley, Perth, WA 6102, Australia; \\ philipjhbay@yahoo.com \\ * Correspondence: swapan4794@gmail.com; Tel.: +61-469-870-695
}

Received: 7 April 2018; Accepted: 25 April 2018; Published: 30 April 2018

\begin{abstract}
The residential built form, including open space, provides the physical environment for social interaction. Understanding urban open space, including semi-public and public domains, through the lens of physical accessibility and visual permeability can potentially facilitate the building of a sense of community contributing to a better quality of life. Using an inner-city suburb in Perth, Western Australia as a case study, this research explores the importance of physical accessibility patterns and visual permeability for socialising in semi-public and public domains, such as the front yard and the residential streets. It argues that maintaining a balance between public and private inter-relationship in inner city residential neighbourhoods is important for creating and maintaining a sense of community.
\end{abstract}

Keywords: community building; quality of life; built form typology; front-yard; physical accessibility; visual permeability; human behaviour

\section{Introduction}

A major aspect of social sustainability is the ability to foster resilient communities through the development of a sense of community and encouragement of social interactions. The role of public places as a prime component of the physical living environment in contributing towards community building has been the subject of many studies. Public places within a commercial setup, such as shopping areas, markets, arts districts, entertainment areas, café and restaurant precincts, have been of a particular interest. The main assumption is that a well-designed physical environment can stimulate social mixing as well as easy contact between people. Studies of such social interactions, however, are rare. As the sense of identity is often lost in a commercial public space, measuring interaction can also be difficult [1].

Social interactions within inner-city residential areas and neighbourhoods have been particularly unexplored. A lot of potential for community building lies beneath the soft edges of residential streets, including the house fronts [2]. In fact, house fronts are the ground which accommodates various activities promoting socializing between neighbours. Their physical characteristics shape the streetscape and the social interactions define the entire community.

As an integral part of a dwelling, the front yard is considered a common land between the street and the house front and is often found in residential suburbs in Australia [3], United States [4], Canada [5-7], and Europe [8-12]. Front yards vary in size, shape, and style according to geographical position, local planning regulations and design $[13,14]$. Generally, the front yard is used for different 
social, economic or climatic [15] purposes, such as vegetable growing, household works, beautification, gardening and recreation [16].

The front yard is privately-owned but has high potential to act as a public space. Although the front yard is legally private, if visible from the street, it is considered as part of the public realm [17,18]. Thus, it is termed as "semi-private-public" for its omnipotence ownership character. This means front yards can accommodate mixed activities which involve users with the space and are able to contribute towards enhanced socialising. Moreover, residents' perception $[17,18]$ about the front yard's usability has a keen influence on social activity patterns. The physical condition-physical accessibility and visual permeability - of the front yard is directly related to creating sense of community.

Despite the relative importance of house fronts, there is limited knowledge about the front yards in residential streets of inner-city suburbs. This potential built form and its typology require better understanding in terms of social interaction and physical articulation. Hence, a focus of this paper is the contribution of the front yard towards community building and sense of community through its characteristics of physical accessibility and visual permeability. It analyses one specific residential neighbourhood in the inner-city suburb of Subiaco in Perth, Western Australia.

\section{Background}

Advocates of mixed-use, high-density development, such as Jane Jacobs [19] assert the necessity of mixed urban layout and design for vibrant urban communities while acknowledging the importance of the relationship between design and human behaviour. There are also implicit suppositions that this urban form will lead to improved quality of life [20-22].

The visual appearance of the urban form has been overlooked by planning processes, activities and intentions [23] with "physical characteristics" seen as individual preferences rather than a "theory" that informs design [24]. In reality, the physical characteristics of cities have a significant impact on travel behaviour and patterns of movement, along with economic viability, real estate market dynamics, social equity, energy use and overall sustainability [25]. Many urban planning guidelines for urban design since the 1990s have aimed at optimal density, mix of use and better access to local facilities [26], but have not focused on the importance of how the built environment is perceived [22]. Whilst differences in residential density influence the establishment of social networks and relationships, physical factors such as public space location, urban form types and physical forms are important design elements which shape neighbourhoods, the way people relate to them [22] and the presence of a sense of community $[27,28]$. The house fronts contribute to the physical appearance of residential streets and are the interface between the public and private spaces providing distinctive neighbourhood identities.

\subsection{Semi-Private-Public Space}

If the house front includes a front yard, front garden, entrance deck, plinth, veranda, porch or forecourt, this space becomes the main area of public-private interface. The front portion of the house in all its different forms is something in between indoor and outdoor, leading from inward to outward to pedestrian walkways, such as sidewalks or footpaths, and ending in the street (or vice versa). This range of built form typologies describing the house front is termed as "semi-private-public" in this research as they represent the interface that interacts between the private and public domain of the inner city residential living environment. The potential the semi-private-public interface has to enhance social interaction between neighbours is evident in older traditional suburbs and is also important for any community building.

In the field of planning, urban design and architectural theory, the urban interface between public and private has become an important concern. Interface types, such as access, setback, transparency or mode of access, are evident in Australian inner-city contexts [29]. The transitory or interstitial spaces between private and public welcome friends and business; create identity at the foyer, front door and front garden; encourage socializing at the front porch and al fresco dining; establish boundary and 
natural surveillance ensuring the feeling of safety [19,29]; offer transparency through gardens and front setbacks facilitating social activities [30]. This interface balances power relations at access where privacy acts as a stabilizer between private and public [31]. Simmel [32] equivocated interface as separating and connecting device where strangers are greeted or excluded [33], where exposure and confidentiality coexist. It provides opportunities for prolonged outdoor stays therefore increasing social interaction among community members and providing important opportunities for participating in public life [2]. The semi-public-private spaces shape commercial as well as residential streets, contributing to a sense of place.

\subsection{Residential Streets}

The street nowadays is perceived as an essential sociable and livable public space, able to accommodate various activities in the urban environment [34]. While there have been studies of mix-used streets in residential neighbourhoods, the emphasis has been mainly on the commercial functions, such as retail, work, cultural and light industrial uses [35]. Plazas and squares have also attracted a lot of research attention [36-45]. There is, however, limited research on purely residential streets and spaces [46-50] and very little is known about people's behaviour in the semi-private-public areas of the house fronts. While urban designers and planners found that physical environment and social activities are inseparable in contributing to life experiences [51], not much effort exists in bringing the two together within the residential street. Understanding the daily life activities within the physical settings does have the potential to facilitate community building but so far remains largely unexplored.

\subsection{Studying Residential Semi-Private-Public Spaces}

The relationship between the built form typology characteristics of residential streets and the behaviours and activities that take place can provide insights as to what extent the physical settings are able to support building sense of community [52]. In 1968, Barker [53] referred to this relationship as "behaviour settings" and the better they are, the more positive feelings, needs and interactions are likely to develop [35]. The house fronts, and the front yards in particular, offer unique surroundings for people to establish contact, share activities and spend time interacting with others. Observation can be used to register and analyse human behaviour in these semi-private-public spaces [54-57], including measuring of social interactions.

Although so far the front yard has attracted very limited attention, there have been other neighbourhood-based studies. For example, in 1972, Appleyard and Lintell [58] measured the frequency of social interaction by analysing familiarity, home territory and environmental awareness in different streets of the same neighbourhood. In his 2011 analysis, Gehl [59] measured social interaction by counting daily life activities in the "soft edges" between buildings. Raman's [22] 2010 study emphasised that the physical environment can mediate social behaviour and neighbourhood membership while in 2013, Groat and Wang [60] argued that there is no need to show causal relationships between such variables as they are mutually reinforced. Hence, observation is a good method to track human behaviour in a city, neighbourhood [61] and in the semi-private-public spaces of the front yards.

Furthermore, people's perceptions also play an important role in shaping human behaviour. Residents' perceptions can influence how the built environment is used [62] and the development of sense of community. In general, the physical qualities, social environment and residential satisfaction are interrelated [63-65]. Hence, in addition to observation, surveying people and collecting information based on their perceptions can be a useful tool to study semi-private-public spaces, such as the front yards.

There is one main characteristic of the semi-private-public places in residential neighbourhoods which is crucial for social interactions, impacts on behaviour patterns and needs to be analysed. It is their accessibility described as physical accessibility or ease of access-that is, how easy it is to 
enter and use the semi-private-public space - and visual accessibility or permeability-that is, ability of human sight to pass through and observe the material features located there. Easy accessibility to a physical space can ensure smooth social interaction. A frequently accessible space generates familiarity, intimacy, attachment and thus encourages residents to get involved in community related activities $[31,66,67]$. Visual permeability of the semi-private-public spaces ensures psychological connection to the street and other public areas.

The social connectivity between the front yard and the street can be seen as directly proportionate to the degree of physical accessibility and visual permeability. Observation and perception studies can potentially measure and evaluate these two accessibility aspects of the semi-private-public spaces as well as contribute towards understanding their role in building sense of community.

\subsection{The Front Yard}

The aspects of physical accessibility and visual permeability have been considered seriously in the local planning scheme of Australia [68,69], United States [4,16], Canada [5,7], and all over Europe $[9,10,70]$. Back in 1829, the front yard was regularised in Australia by a mandate as a buffer space between the house and the street [13]. Front yard is also a widely accepted suburban built form type in North America [71]. Influenced by the trend in USA [72,73], many Australian houses adopted the fenceless open front yard to increase social interaction between neighbours and decrease anti-social activities [68].

Identity or personalisation makes a place unique, attractive and recognisable, determines what it is and how it differs from others. Personalisation of the physical environment can fulfil needs to participate in desired activities [52]. It creates sense of occupancy and control over the space which encourages people to maintain the physical environment in a distinctive manner, often involving design professionals [74]. For visitors, personalisation creates interest [2], generates comfort [35] and promotes casual leisure behaviour [75,76].

Front yard ornamentation (including gardening and planting) is a common practice that engages neighbours in social interaction [77] and thus helps to build a strong visual language for visitors. Neighbours not only apprehend through compliments, but also actively socializing during gardening in the front yard [78]. Active participation in the front yard promotes strong social interaction without the need to be a member of local clubs [79]. This "simultaneous visual diversity" [77,80] is a "common symbol system" [81,82], which is a prime component of sense of community.

Front yards vary in relation to physical accessibility, be it pedestrian or vehicular [83], and visual connectivity — that is, the ability to be seen $[17,18]$ - from the public domain and this controls the level of social interaction between household residents, neighbours and pedestrian users. Use of fence, boundary wall, gate, vegetation, hedges and screening are common practice in the front yard to provide identity, privacy and control access. These devices serve both physical and visual purposes in terms of the public-private relationship between indoor and outdoor spaces.

In the early 1970s, Newman's $[84,85]$ work showed that the physical design of a space can promote better social phenomena and thus is able to enhance the sense of security which is an element of sense of community. Newman's "socio-physical" $[84,85]$ space is based only on a sense of security which is not enough to understand the sense of community. Thus, further exploration of social interaction, attachment and identity $[82,86,87]$ is required to enhance community building. During the 2000s, Pollan [72] and Jurkow [79] identified the front yard as a "vehicle of consensus", that is collective identity, rather than an "area of self-expression" and privacy, which indicates its semi-private-public nature. Physical accessibility, visual permeability and personalisation are important features of the front yard which this research intends to investigate as they determine the intensity of socialisation between neighbours. A case study example from a residential neighbourhood in Perth, Western Australia is used for this purpose.

The remainder of the paper first examines the connection between accessibility and sense of community from a theoretical point of view. It then presents the methodological framework for the 
case study based around accessibility of front yards. Subiaco-a residential area in Perth and the case study for this analysis-is described in terms of physical accessibility and visual permeability using observation and survey of people's perceptions. The concluding section emphasises the importance of the front yard as a vehicle for social interaction and community building.

\section{Accessibility and Sense of Community}

This research explores the scope of user-oriented physical environment to facilitate social interaction and promote community building within a residential neighbourhood context. Neighbourhood streets represent a behaviour setting which shapes potential behaviour patterns, physical articulation and design. Physical accessibility to a space, such as a front yard or veranda, varies and depends on the actual design. For instance, a fence, wall or vegetation can work to a different degree as a physical barrier [85]. Maximum physical access is ensured when there is no boundary wall between a front yard and sidewalk or pedestrian pathway. Similarly, maximum visual permeability is established when the semi-private-public spaces, e.g., the front yard, are seen from the public area, e.g., the sidewalk or street [79]. According to Chua [86], community building tends to develop where familiarisation through seeing, meeting and greeting takes place in common areas, such as walkways [87] or the front yard.

Hence, the physical design regulates the degree of accessibility, physical and visual, into semi-private-public domains which in turn influences social interaction $[38,51,52]$. The relationship between the built form as represented by the front yard and social interaction directly influencing the sense of community, is mediated through accessibility (in its physical and visual form), which is the prime concern of this study (see Figure 1).

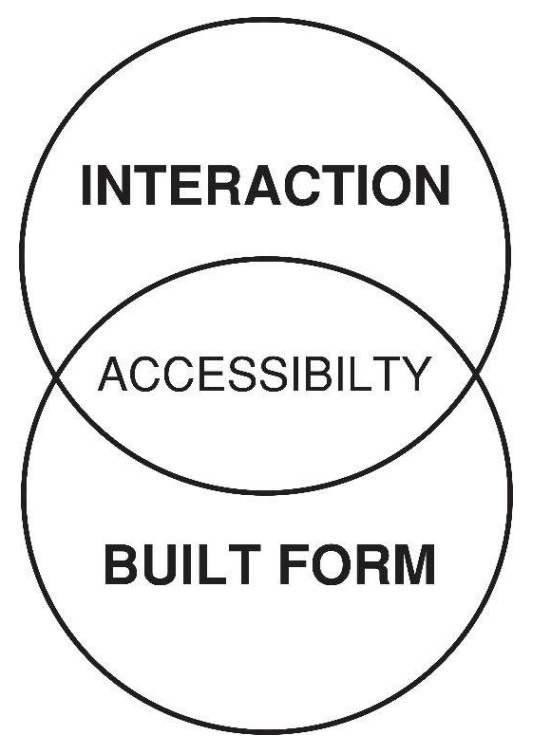

Figure 1. Relationship between built form and social interaction.

Social interaction is ultimately aimed at establishing sense of community. David McMillan and David Chavis [82] and David McMillan [88,89] define sense of community through four elements, namely: (1) membership or later described as spirit; (2) influence or trust; (3) reinforcement or trade; and (4) shared emotional connection or art. The factors which influence the sense of community include: interaction with neighbours, feeling of safety and desire to participate in neighbourhood affairs or localism [90,91].

Membership means the feeling of belonging or being part [92] as a member [93,94] of a body, group or organization. Elements defining membership are boundaries, emotional safety, sense of belonging and identification, personal investment and a common symbol system [89]. They help develop a 
particular spirit of friendship or emotional feeling which allows people to connect to others and express their personality [88,95]. Examples of the common symbol system may include maintaining lawns, keeping front yards and sidewalks tidy [96]. In contrast, an untidy front yard affects the sense of attachment and discourages people to associate with this particular place [97]. There might also be negative impacts on the sense of safety as well as social interaction [98].

Influence is described as the ability of a community to influence its members and vice versa which is based on the trust they have in each other [88]. Related to the urban built form and semi-private-public spaces, influence is expressed by the adopted designs, norms and expectations about appearance and social behaviour. Reinforcement or trade represents the bargaining process through which community needs are fulfilled and resources are met based on shared values, fairness and ultimately through giving $[88,89]$. The front yard offers a space where such reinforcement can occur. When people compete to make their front yard distinct, they "gravitate" towards a group [82] and this is termed as "person-environment" fit [99]. Shared emotional connection is expressed by spending time together and these interactions have to be high quality making the collective experience become art [88]. When people take part in common events (e.g., rituals, festivals or simply doing something together), the sense of community increases. The more the interaction (contact), the closer the relationship [100-103]; the more the successful positive interaction, the more the social cohesion [66].

Sense of community is a crucial element of quality of life which has been missing in developments taking place since the late 1990s. The current trend of extended building footprint is creating architectural, social and cultural problems [75] which results in disappearing of space types such as front yard, sidewalk, verge, parking and even street. By encouraging privacy, recent planning policy does not promote socialising and sustainable community building $[75,104]$. By definition, sense of community is a "feeling" [105] of belonging and of individuals being important to each other; a shared faith that community members' needs will be valued with commitment [82]. Access to appropriate residential outdoor spaces [106] is required to develop such a feeling and promote better socialising at a neighbourhood scale. Table 1 summarises key theories which link physical space with sense of community. This study investigates the front yard as such a space through its accessibility.

Table 1. Key theories.

\begin{tabular}{lll}
\hline \multicolumn{1}{c}{ Theorist } & \multicolumn{1}{c}{ Theory } & Method Used \\
\hline William Hollingsworth Whyte [42,107] & $\begin{array}{l}\text { Improved physical space can promote better social } \\
\text { cohesion to achieve economic gain. }\end{array}$ & Observation Interview Filming \\
\hline Jan Gehl [108] & $\begin{array}{l}\text { Prolonged outdoor stay can promote enhanced social } \\
\text { interaction. Various social dimensions affect human } \\
\text { perceptions during socialisation. }\end{array}$ & Observation Survey \\
\hline Joo Hwa Bay [109] & $\begin{array}{l}\text { Social interaction in residential semi-open spaces } \\
\text { promotes community building. }\end{array}$ & Observation Survey \\
\hline Matthew Carmona [18,110] & $\begin{array}{l}\text { Space typology is an important planning measure for } \\
\text { better management of urban outdoor spaces. }\end{array}$ & Literature review \\
\hline $\begin{array}{l}\text { David W. McMillan and David M. } \\
\text { Chavis [82]; David W. McMillan [88,89] }\end{array}$ & $\begin{array}{l}\text { Sense of community is defined through social interaction, } \\
\text { community attachment, community identity and sense } \\
\text { of ownership/belonging. }\end{array}$ & Literature review \\
\hline
\end{tabular}

During the 1980s, urban designers, such as Gehl [2] and Whyte [42] worked on access to public open spaces in commercial areas. More recent studies segregate the physical environment without considering the relationship between interaction and the built form $[1,51,111]$. Local laws are similarly focused on commercial public place to promote social mixing [112]. Bay's $[109,113]$ work on residential semi-open spaces is rare and in this vein, the current study focuses on the front yard as a built form type in inner-city neighbourhoods which fosters mixed activities and acts as an interactive zone for private and public interactions. 
The front yard and its functions as a semi-private-public space is a new frontier in studies about sense of community. It is an intermediate buffer space that helps maintaining public-private inter-relationship between indoor and outdoor. However, there are no proper guidelines on understanding the typological categorisation of this semi-private-public space in the planning scheme. On the other hand, this built form type has tremendous quality to foster social interaction and the current study aims at filling in the gap in knowledge around the front yard. Understanding daily life activities in this physical setting potentially contributes to community building and needs further development in academic knowledge and application to practice.

\section{Methodology}

This study uses a mixed method approach $[60,114]$ which includes:

- $\quad$ Case study [115];

- $\quad$ Resident survey through interviews [116,117]; and

- Detailed observation $[1,2,25]$.

\subsection{Case Study}

The case study method is appropriate for complex social investigations [115] and is used to understand what is happening within the residential streets of one particular inner-city area. Once the area of study is defined, different approaches to data collection can be used to describe social behaviour. Whyte [42] and Gehl [2] observed behaviour of ordinary people on the streets mainly as a result of chance encounters. Meeting a familiar face in a public place through chance encounter is rare; on the other hand, residential public places such as streets, sidewalks and passages are common meeting places for the residents. People are meeting each other while participating in daily life activities involving taking children to school, going and coming back to work, regular trips to the grocery shop/mall, walking dogs, bringing children to the park/playground, cleaning the front yard/sidewalk, rolling the rubbish and recycling bins out to the verge and so on. Regular daily life activities are predictable and thus have higher organising potentiality to be considered by urban designers, planners and policy makers [86]. It is possible to regulate these known routes based on resident behaviour patterns to reflect the planning codes. However, it is quite difficult to do it in public places with commercial enterprises. Predictable residential public streets and semi-public sidewalks [86] are integral part of residential areas and intensely interact with semi-private-public front yards.

The chosen case study for analysing social interaction in residential streets and adjacent front yards is Subiaco. Available built form types in Subiaco are veranda, front yard, sidewalk, verge, parking, back-lane and street. These are common shared spaces where various activities take place. Neighbours are meeting each other in those spaces to fulfil their daily life routines or for recreational purposes. We use the case study to assess all key theories listed in Table 1 recognising that the built form condition of these space types in terms of physical accessibility (pedestrian or vehicular) and visual permeability is required to achieve a set of typology. This typological setup can become a useful tool to identify the intensity of social interaction in the Subiaco neighbourhood.

\subsection{Subiaco as a Case Study}

Subiaco is situated at the immediate west of the Perth central business district (CBD), five kilometres east of the Indian Ocean, $12 \mathrm{~km}$ north-east of the port of Fremantle and north of the Swan river (see Figure 2). It is one of the traditional inner-city suburbs of Perth, which was subdivided in 1880 as part of the development process [118]. In the early 20th century, Subiaco emerged as a working-class neighbourhood and by 1950s ranked as the most declined suburb $[119,120]$. In 1970s, dilapidated dwellings attracted families and students from the University of Western Australia and high schools to live in the cheaper rental properties, and thus by 1990s, Subiaco became a culturally vibrant community [120]. It hosts the landmark Regal Theatre, an arts centre, several hospitals, parks, 
shops, cafés and restaurants, community centres and community markets. This leafy green suburb has good connectivity through public transport, including train and bus services, and is considered a stylish and attractive place. Subiaco has numerous outdoor and commercial places for local residents and visitors (see Figure 3).

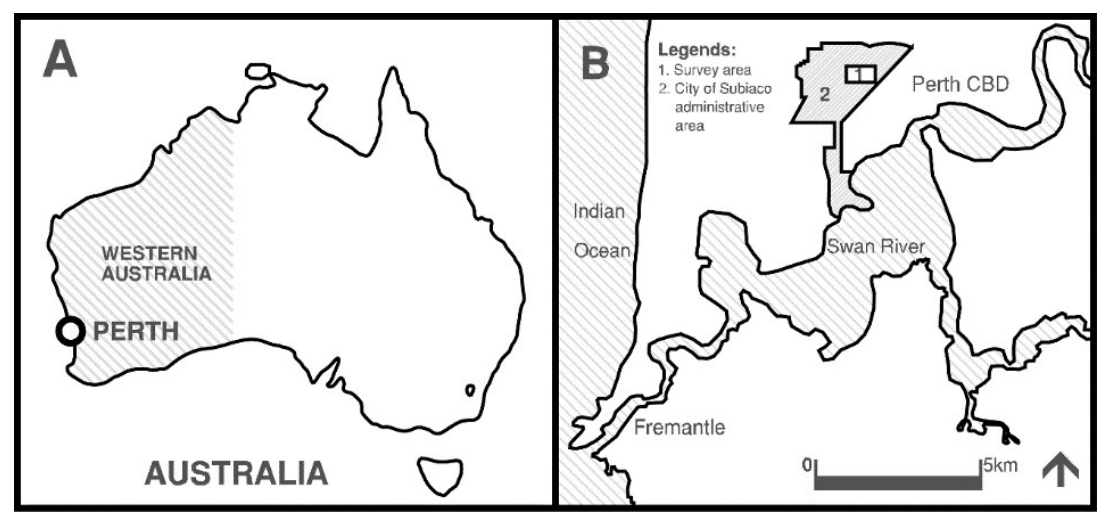

Figure 2. Maps of Australia and Perth: (A) Australia (B) Subiaco.

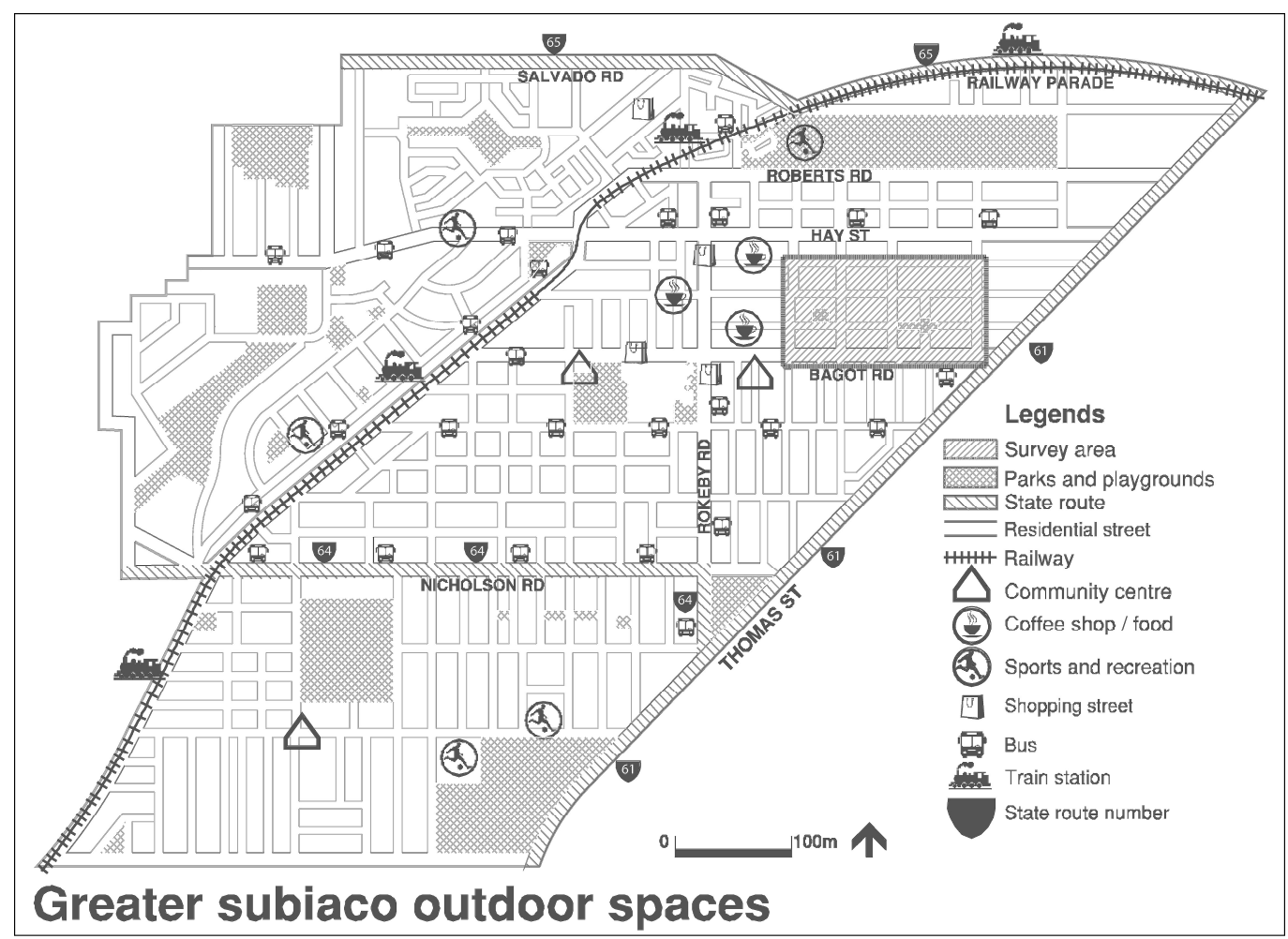

Figure 3. Subiaco outdoor destinations around the surveyed neighbourhood.

According to the Australian Bureau of Statistics, the total land area of Subiaco is 558 hectares (5.6 square kilometres) and its population was 17,238 in 2017 [121], with a density of 30.89 persons per hectare. The average resident wages and salary income for Subiaco was AUS\$ 68,931 in 2009 with an annual growth rate of $6.7 \%$ [122]. Nowadays Subiaco remains a relatively wealthy area with a higher proportion of people earning a high income compared to the rest of Perth [123]. 


\subsection{Analysed Neighbourhood within Subiaco}

The surveyed area in Subiaco was narrowed down to a manageable size for a detailed analysis (see Figure 4). It excludes commercial areas or industrial enterprises and public open spaces and includes several residential streets, namely Axon Street, Townshend Road, Olive Street, Bedford Avenue, Barker Road, Park Street and Bagot Road (see Figure 4). All streets have house front yards in a face to face and side by side manner, that is each house has a front yard and is surrounded by other houses in the same street and across the street. Such physical settings ensure ultimate probabilities for social interaction between neighbours within their immediate vicinity. As already indicated, the frequency of social interaction is directly related to the sense of community. The study of this neighbourhood analyses the physical and visual accessibility of the different space types on the seven residential streets.

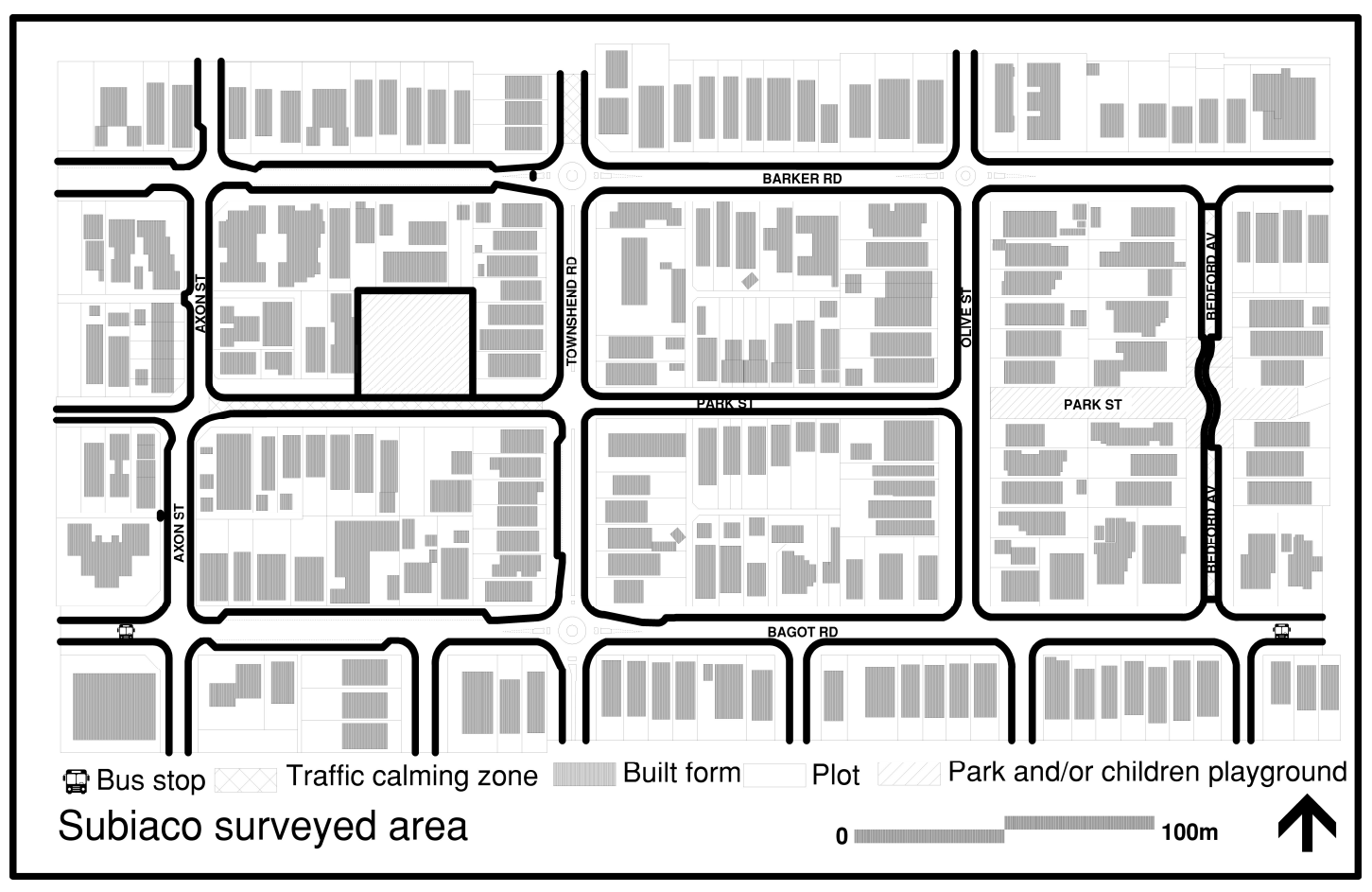

Figure 4. Analysed neighbourhood in Subiaco.

\subsection{Interviews}

Interviews are based on individual perception by local residents as a way to inform the study of the residential neighbourhood of Subiaco. A semi-structured interview design was adopted which contains questions related to demographic information (age, profession, use hours of front-yards, etc.), opinion (based on a Likert scale) and open-ended questions (allowing local residents to share comments, suggestions and recommendations). The survey which had approval by the Curtin University Research Ethics Committee was conducted door to door in different suitable locations only on residential streets in Subiaco (refer to Figure 4) excluding any commercial or public enterprises and at convenient times. Residents were informed about the purpose and aim of the survey, ensured about their anonymity and requested to sign a written consent form. The survey was conducted during the spring and summer seasons of 2016 and 2017 in different daytimes of weekdays and weekends. 
A total of 61 residents responded to the survey which took at least 15 min and no more than $25 \mathrm{~min}$ to complete. Most respondents found it easy to visualise the answer to the questions while standing in their front yard, front deck or stoop (a small porch with a few stairs ending with a platform in front of the house entrance). Jane Jocobs refers to the stoop [19] as a space for natural surveillance which is able to prevent crime on the street. A few residents were comfortable to respond in the nearby sidewalk, park and corner of the street.

\subsection{Observation}

Observation was carried out of: (a) the front yards and (b) the street in a small area (see Figure 4) covering seven different streets. The physical and visual accessibility patterns in the front yards of these streets were recorded. Creating a new typology that enhances socialising in the front yard and the concepts of accessibility [83], such as level of physical accessibility and visual connectivity, is crucial in influencing the level of social interaction which is directly related to sense of community.

\subsection{Neighbourhood Front Yard Taxonomy in Subiaco}

For the Subiaco neighbourhood, three types of front yards were identified in relation to physical accessibility, namely A1-highly accessible, A2-accessible or somehow accessible, and A3-not accessible (see Table 2); and visual permeability, namely V1-highly visible, V2-visible or somewhat visible, and V3-not visible (see Table 3).

Physical accessibility through boundary walls, gates, hedges and other features, is a factor influencing social interaction in a residential area. Jan Gehl [2] identified walls as a factor influencing contacts and intensity of interaction between people. A boundary wall resembles the owner's attitude towards public. Open front yards without any boundary walls give an inviting impression while gated and locked front yards are just the opposite. The degree of openness is a factor that allows neighbours to get into the semi-private-public realm of the front yards. When a postal or pizza delivery person can get access to the front door's bell, it is considered welcoming. Some front yards have unlocked gates and are considered as "somehow accessible" as outsiders are still allowed access to the front yard. Closed gates with or without an intercom are considered "not accessible". A solid boundary wall higher than 6 feet is considered a complete barrier between residents and visitors and the front yard is not suitable for social interaction.

The human being has a 180-degree front-facing horizontal visual field [124]. Both downward and upward visions are narrower than the horizontal one. Upward vision is much narrower as humans have a tendency of looking downward while walking which makes the axis of vision 10 degrees further downward. Such a walking person practically can see only activities at ground level, streets, sidewalks and front yards. The level of perception about visibility depends on the visual permeability of the front yard. Walls, fences, vegetation and screens control the visual permeability level between the street and front yard as outlined in the three categories. 
Table 2. Types of physical accessibility.

\begin{tabular}{ccccc}
\hline Boundary Features & Boundary Height & Intensity Scale & Code \\
\hline No boundary & & & \\
& & & \\
Highly & Accessible & A1 & & \\
\end{tabular}

Low wall/fence/hedge (usually without any gate/control; anyone can get into the front yard; low wall is just a sense of boundary and means of sitting and easy to tip over even for a child)

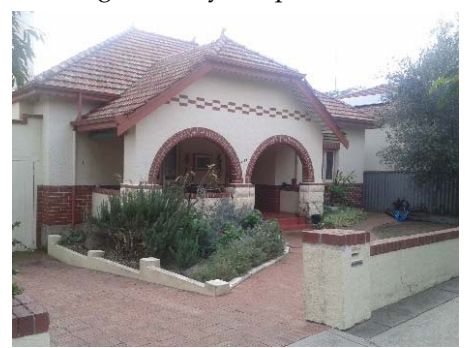

$3^{\prime} 0^{\prime \prime}$ maximum Accessible

Gate closed but unlocked, so that meter reader can enter to reach

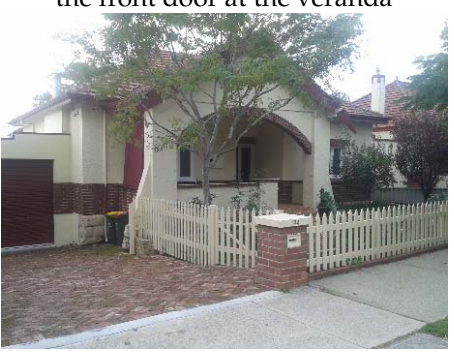

$4^{\prime} 0^{\prime \prime}$ maximum Somehow accessible

Gated/with intercom or calling bell/without any option to knock on the door.

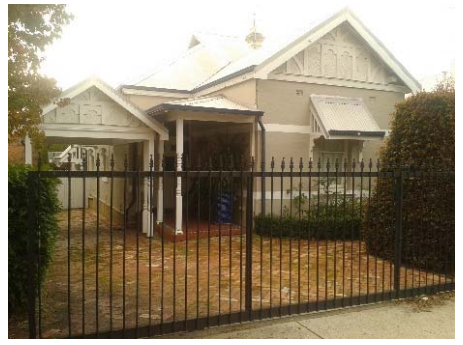


Table 3. Types of visual permeability.

\begin{tabular}{cccc}
\hline Visibility Features & Boundary Height & Intensity/Scale & Code \\
\hline No visual barrier/screen/plant/tree & & & \\
\hline$(6)$ & & & \\
\end{tabular}

Low height visual barrier (wall/fence/hedge)

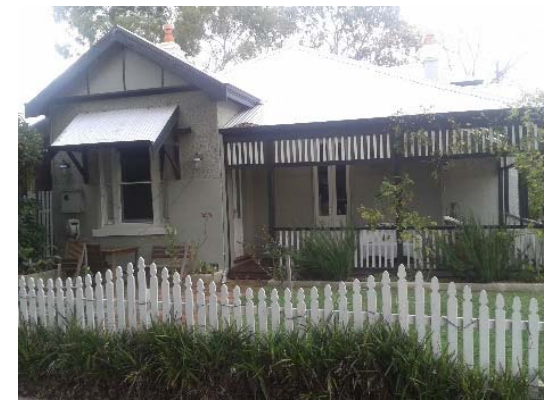
$3^{\prime} 0^{\prime \prime}$ maximum
Visible

Medium height visual barrier

(wall/fence/hedge)

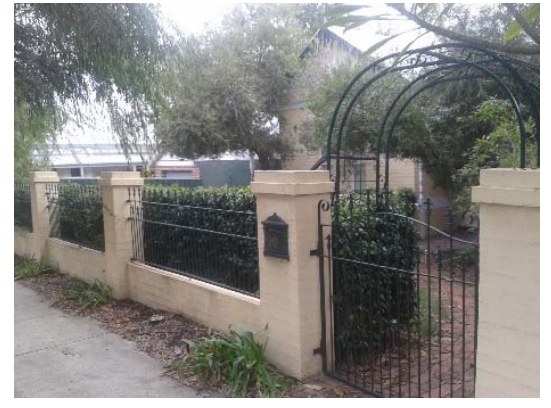

$$
4^{\prime} 0^{\prime \prime} \text { maximum Somewhat visible }
$$

Very high visual barrier (wall/fence/hedge)

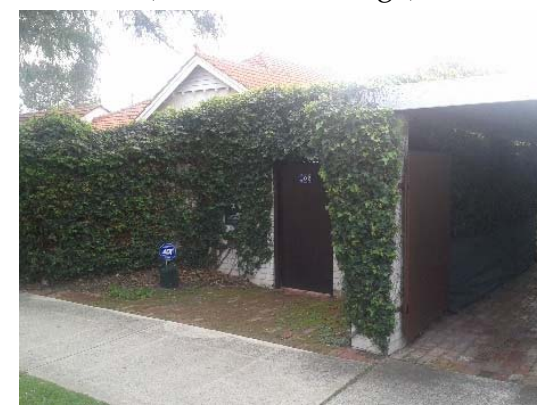

$4^{\prime} 0^{\prime \prime}$ to $6^{\prime} 0^{\prime \prime}$ or more Not visible

V3

\section{Case Study Results}

Out of the seven neighbourhood streets included in the accessibility analysis, four-namely Axon Street, Townshend Road, Olive Street and Bedford Avenue-have a north-south orientation while the 
remaining three-namely Barker Road, Park Street and Bagot Road—are along the east-west direction. The houses included for each street are based on their front yard orientation rather than physical address. For instance, in this research the front yard orientation of a corner plot works as a decisive factor for a street even if it falls under the other street according to postal address. Moreover, the front yard orientation is important to observe the face-to-face (houses opposite to each other) or side-by-side (houses adjacent to each other) interaction level among immediate neighbours. Table 4 shows the number of houses analysed in each street.

Table 4. Accessibility patterns in the analysed Subiaco neighbourhood.

\begin{tabular}{|c|c|c|c|c|c|c|c|c|c|c|}
\hline \multirow{3}{*}{ Street } & \multirow{3}{*}{ Number of Houses } & \multicolumn{3}{|c|}{ Physical Accessibility } & \multicolumn{3}{|c|}{ Visual Accessibility } & \multicolumn{3}{|c|}{ Overall Accessibility $^{1}$} \\
\hline & & High & Medium & Low & High & Medium & Low & & & \\
\hline & & A1 & A2 & A3 & V1 & V2 & V3 & nign & IViedim & Low \\
\hline Axon Street & 9 & 0 & 56 & 44 & 0 & 67 & 33 & 0 & 61.5 & 38.5 \\
\hline Townshend Road & 30 & 8 & 71 & 21 & 67 & 12 & 21 & 37.5 & 41.5 & 21 \\
\hline Olive Street & 27 & 29 & 54 & 17 & 25 & 58 & 17 & 27 & 56 & 17 \\
\hline Barker Road & 50 & 10 & 77 & 13 & 58 & 29 & 13 & 34 & 53 & 13 \\
\hline Park Street & 34 & 18 & 49 & 33 & 30 & 43 & 27 & 24 & 46 & 30 \\
\hline Bagot Road & 52 & 17 & 67 & 16 & 27 & 58 & 15 & 22 & 62.5 & 15.5 \\
\hline All streets & 219 & 16 & 65 & 19 & 40 & 42 & 18 & 28 & 53.5 & 18.5 \\
\hline
\end{tabular}

\subsection{Physical Design and Accessibility}

The link between the physical design and accessibility of the front yard was assessed based on a complete observation of all houses in this neighbourhood. None of the houses on Axon Street have high physical or visual accessibility. Nevertheless, $56 \%$ are physically accessible and $67 \%$ of the front yards are visible (see Table 4). The remainder are not accessible at all. When the physical and visual accessibility percentages are averaged for each category to represent the overall accessibility, just over $60 \%$ of the houses in this street have potential for socialising. Although there are houses with high accessibility in Park Street, the majority have medium accessibility and with the overall percentage for socialising at $70 \%$, there is potential for social interactions (see Table 4 ).

By comparison, Townshend Road is very different as it has a much smaller number of houses with no accessibility at all and $79 \%$ of all houses are overall accessible (see Table 4 ). Thus, it can be concluded that this street has a high potential for socialising. Olive Street, Bedford Avenue, Barker Road and Bagot Road similarly have high potentials for socialising with the respective overall values being $83 \%, 93 \%, 87 \%$ and $84 \%$ (see Table 4 ). The value for the entire neighbourhood is also high at $82 \%$.

Hence, the majority of front yards on the residential streets of the analysed Subiaco neighbourhood have potential for social interactions based on accessibility to this semi-private-public space. In six of these inner-city residential streets, the potential for socialising is high. Such a typology of the front yards can contribute to planning policy in its efforts to create sense of community. As far as the physical design of this Subiaco neighbourhood is concerned, it encourages social mixing and easy contact between people boosting membership, influence, reinforcement and shared emotional connections. Were the physical design deprived of front yards or were there to be an overwhelming share of houses with not-accessible semi-private-public places, the conditions for developing a sense of community would have been very different.

However, it is interesting to compare the findings about social interactions based on the physical design of the front yards with the actual perceptions people have about the place of this semi-private-public space in their lives. 


\subsection{Perception and Accessibility}

The results from the perception survey of the Subiaco neighbourhood are presented in Table 5 . According to the majority of people (67\%), the physical condition of their front yard helps them socialising. About $60 \%$ of the residents think that the front yard works as an extension of their living area for socialising with neighbours. Most residents $(80 \%)$ are very conscious about the visual accessibility of their front yards, which helps to communicate with their neighbours in public spaces like sidewalks and streets. Front yards are visible enough (67\%) from the streets and sidewalks with their distinct "personal expression" (64\%). These visual and physical characteristics of the front yards are helping create sense of community.

Most of the respondents (64\%) actively maintain an interactive public-private relationship while communicating with their neighbours. Just under half of people $(48 \%)$ spend at least one hour a day during weekdays and $52 \%$ use it two to five hours a day during weekends. That means the front yard is a frequently used immediate semi-private-public space which maintains a balance between public and private interactions. A significant number of residents (77\%) feel a strong sense of ownership and belonging in relation to their front yard; almost all (97\%) feel safe during daytime and a large majority (74\%) also after dark.

Table 5. Perception survey of Subiaco neighbourhood.

\begin{tabular}{lcc}
\hline \multicolumn{1}{c}{ Statement } & Agree & Aspects \\
\hline The overall physical condition of my front yard helps me socialising. & $67 \%$ & Physical accessibility \\
\hline $\begin{array}{l}\text { The front yard is an extended living area for socialising with } \\
\text { neighbours or guests. }\end{array}$ & $60 \%$ & Physical accessibility \\
\hline $\begin{array}{l}\text { Front yard visibility from the street to communicate with neighbours in } \\
\text { adjacent walkways or streets helps residents engage with } \\
\text { neighbours for socialising. }\end{array}$ & $67 \%$ & Visual permeability \\
\hline $\begin{array}{l}\text { The visibility of the front yard from the street allows natural surveillance } \\
\text { and the feeling of safety. }\end{array}$ & $80 \%$ & Visual permeability \\
\hline $\begin{array}{l}\text { The front yard has its own distinct "personal expression" which contributes } \\
\text { to the physical or visual characteristics of the street. }\end{array}$ & $64 \%$ & Visual permeability \\
\hline $\begin{array}{l}\text { The front yard works as part of the street which helps me maintain a good } \\
\text { relationship between public and private domains. }\end{array}$ & $64 \%$ & $\begin{array}{l}\text { Interaction and } \\
\text { communication }\end{array}$ \\
\hline $\begin{array}{l}\text { I like to spend at least } 1 \text { h during weekdays in my front yard. } \\
\text { I like to spend } 2 \text { to } 5 \text { h during weekends in my front yard. }\end{array}$ & $48 \%$ & Activity \\
\hline $\begin{array}{l}\text { I feel a strong sense of ownership and sense of belonging in the front yard } \\
\text { of my house that help me engage with my neighbourhood community. }\end{array}$ & $77 \%$ & Activity \\
\hline $\begin{array}{l}\text { I feel safe using the front yard while participating in } \\
\text { activities during daytime. }\end{array}$ & $97 \%$ & Sense of belonging \\
\hline I feel safe using the front yard while participating in activities after dark. & $74 \%$ & Sense of safety \\
\hline
\end{tabular}

Overall, there seems to be a good match between how people feel about the front yard and its physical design in the context of socialising, establishing relationships and community building. Understanding the social mixing potential of the physical environment is vital, but it would not be put into good use unless residents also perceive these opportunities.

\section{Discussion}

Urban public place is most essential to make a city liveable. Quality urban spaces foster sense of safety, sense of belonging, increased consciousness, diverse activities, self-esteem and interest in the living environment [125]. People's experiences in an urban environment are reinforced by symbols, myths, customs, faiths, conventions, ceremonies, vacations [82], stories, music and various symbolic expressions [89] which create a sense of community and provide deep intense links and strong integration. 
Residential streets represent typical public space which can be extended with the opportunities for socialising provided by the semi-private-public place represented by the front yard. From the observation of Subiaco residential streets, it is evident that the boundary design (high wall-low wall), fencing style (material, design, transparency), front yard orientation, veranda design are clear symbols that can be attributed to various activities and behaviours of the local residents. The majority (64\%) of Subiaco residents (see Table 5) think that the "personal expression" of their front yard is able to influence to the physical and visual characteristics of their streets and thus contributing to the community. Architecturally, the front yard-a small-scale built form type with distinct characteristics-is contributing to the overall streetscape and thus helps maintaining the entire street typology through a process of continuous evolution [126-128]. This study is one of the few to shed light on the present-day importance of residential streets and the annex between the public and private spaces in them.

Shared emotional connections related to history, common place, time together and similar experience help build sense of community. The front yard is the new frontier in this research as it allows enhanced social interaction which brings people closer [100-103]; quality experiences with positive interaction and stronger relationships and bonding [66]; investment in time spent together which increases the importance of neighbours and their value to the neighbourhood [93,129], generating a spiritual bond expressed through the sense of community. When communities are forming, members search for others to share issues and then bonding forms as they explore similarity among themselves and reach out for "consensual validation" [89]. The front yard offers such a valuable safe and intimate place [130].

Methodologically, this study showed coherent positive outcomes in two tiers of analysis. First, the selected case study Subiaco neighbourhood demonstrated the significance of the physical typology and second, the perception study of the front yard validated the importance of sense of community. As social elements are more suitable to measure sense of community than environmental ones [131], this study endorses the quality of the front yard as a high potential socially interactive outdoor space type to promote community building and community resilience [132]. It helped put the importance of the front yard in perspective in relation to the elements of sense of community identified by McMillan and Chavis [82,88,89], namely social interaction, attachment, identity and sense of ownership (refer also to Table 1). The role of this semi-open space as outlined by Bay [109] was extended to its functions as a semi-private-public place when there is suitable physical and visual accessibility. High quality physical space as described by Whyte [42,107] and prolonged outdoor stay as advocated by Gehl [108] are facilitated by the specific features of the front yards in the analysed neighbourhood. Finally creating a physical typology can assist in better planning of urban outdoor spaces $[18,110]$ by taking into consideration the role of the front yards.

This research is in line with other previous work which shows that lower fences with more visual openness provide better socializing opportunities between neighbours [133]. Similarly, it supports findings that residential built form with semi-public open space promotes more social mixing between neighbours $[134,135]$. Furthermore, our results passively endorse the importance of safety and walkability [134] as well as closely articulated residential built form [136,137] which improve social interaction within a neighbourhood.

A limitation of this study was the data collection carried out by a single person. Better verification and triangulation of the results might have been achieved with multiple observation. Furthermore, the data collection was conducted during spring and summer which are the seasons with more outdoor activities. Although autumn activities are likely to be very similar, the winter season which is colder and with rainy periods might generate some unexpected results. Further research directions can include analysis of the front yards within mixed-use streets where residential and commercial properties co-exist. 


\section{Conclusions}

Researchers and planners consistently acknowledge the importance of fostering sense of community [28,138-143]. In contrast, anti-suburban critique [144] condemns Australian suburbs for being isolated from real life, lack of community and one-dimensional consumer culture.

Most of the available studies looking at the relationship between built form and sense of community are focused on public spaces and plazas in commercial areas. There is very limited research on residential streets. This study helps fill this gap by looking at the relationship between physical settings and potential for socialising in residential areas. It emphasises the importance of the front yard as a semi-private-public space for community building and adds to an area that has been neglected in academic research and planning practice.

Advocates of public place $[2,17,18,145]$ have realized that the front yard is a high-potential private space which can perform publicly. It provides the connection between the private and public realm and is categorised as a semi-private-public place. The analysis of the Subiaco neighbourhood confirmed this nature of the front yards as well as the role of accessibility in fostering social interactions.

In local laws, the importance of the front yard typology is neglected, except for some setback rules. It is important to understand the front yard types to maintain the homogeneity reflected in local planning policy objectives adopted by the City of Subiaco (Planning Policy No. 4.8) [146]. The desire for residential privacy is reflected in local building regulations (see clause 7.1 Visual Privacy, in R-Codes, Residential Design Codes of Western Australia) [147] which could be fulfilled in back yards and outdoor private domains. However, the front yard should be understood as a focused device to maintain interactive relationship between the private and public domain [106]. In architecture, a buffer space is required to ensure gradual and smooth transformation between private and public which is termed semi-public $[145,148,149]$. In a similar vein, the front yard can be defined as semi-private-public space which is capable to equally satisfy both private and public needs. Thus, this magnificent space has tremendous potential to enhance the quality of sense of community and promote community building in the neighbourhood.

Public spaces are often impersonal, and it is hard for a person to maintain individual identity while in the crowd [150]. Front yards work as a public space [18] where people do not lose their personal identity. Moreover, activities in and around the semi-private-public place can contribute to community building. This is the beauty of this amazing intermediate space where people can enjoy their full freedom of choice to participate in activities. The semi-private-public front yard thus accommodates various social activities without losing its distinct physical identity. Users do not feel inferior in this socially interactive physical setup. It is hoped that this research can not only bridge the existing gaps of understanding the front yard but that the new knowledge can help guide designers, developers, consumers and policy makers in making more attractive and resilient residential cities.

Author Contributions: Abu Yousuf Swapan, Dora Marinova and Joo Hwa Bay conceived and designed the study; $\mathrm{Abu}$ Yousuf Swapan performed the data collection and analysed the results. Abu Yousuf Swapan, Dora Marinova and Joo Hwa Bay wrote the paper.

Acknowledgments: Funding for research and publication was provided by Curtin University.

Conflicts of Interest: The authors declare no conflicts of interest.

\section{References}

1. Mehta, V. Lively Streets: Exploring the Relationship between Built Environment and Social Behavior, 2006. Available online: https:/ / drum.lib.umd.edu/bitstream/handle/1903/4165/umi-umd-3962.pdf?sequence= $1 \&$ is Allowed $=y$ (accessed on 25 April 2018).

2. Gehl, J. Life between Buildings; Van Nostrand Reinhold: New York, NY, USA, 1987.

3. Reilly, J.W. The Language of Real Estate; Dearborn: La Crosse, WI, USA, 2000.

4. Kurutz, S. The battlefront in the front yard. New York Times, 20 December 2012: D1. 
5. Stelter, G.; Artibise, A.F.J. Canadian City: Essays in Urban and Social History; McGill-Queen's Press: Montreal, QC, Canada, 1984.

6. Ward, P. A History of Domestic Space: Privacy and the Canadian Home; UBC Press: Vancouver, BC, Canada, 2011.

7. Denhez, M. The Canadian Home: From Cave to Electronic Cocoon; Dundurn Press: Dundurn, SK, Canada, 1994.

8. Smith, M.R. The Front Garden: New Approaches to Landscape Design; Houghton Mifflin Harcourt: Boston, MA, USA, 2001.

9. Biddulph, M. Home Zones: A Planning and Design Handbook; Policy Press: Bristol, UK, 2001.

10. Long, H.C. The Edwardian House: The Middle-Class Home in Britain, 1880-1914; Manchester University Press: Manchester, UK, 1993.

11. Alexander, A. Britain's New Towns: Garden Cities to Sustainable Communities; Routledge: London, UK, 2009.

12. Wouters, C. Informalization: Manners and Emotions since 1890; Sage: Newcastle upon Tyne, UK, 2007.

13. Crittenden, V. The Front Garden: The Story of the Cottage Garden in Australia; Mulini Press: Canberra, Australia, 1979.

14. Troy, P. A History of European Housing in Australia; Cambridge University Press: Cambridge, UK, 2000.

15. Groth, P. Lot, yard, and garden: American distinctions. Landscape 1990, 30, $29-35$.

16. Ford, L. The Spaces between Buildings; JHU Press: Baltimore, MD, USA, 2000.

17. Carmona, M. Contemporary public space: Critique and classification, part one: Critique. J. Urban Des. 2010, 15, 123-148. [CrossRef]

18. Carmona, M. Contemporary public space, part two: Classification. J. Urban Des. 2010, 15, 157-173. [CrossRef]

19. Jacobs, J. The Death and Life of Great American Cities; Vintage: New York, NY, USA, 1961.

20. Rudlin, D.; Falk, N. Building the 21st Century Home: The Sustainable Urban Neighbourhood; Butterworth-Heinemann: Oxford, UK, 1999.

21. Urban Task Force. Towards an Urban Renaissance: The Report of the Urban Task Force Chaired by Lord Rogers of Riverside; Executive Summary; Urban Task Force: London, UK, 1999.

22. Raman, S. Designing a liveable compact city: Physical forms of city and social life in urban neighbourhoods. Built Environ. 2010, 36, 63-80. [CrossRef]

23. Kropf, K. Urban tissue and the character of towns. Urban Des. Int. 1996, 1, 247-263. [CrossRef]

24. Dovey, K.; Woodcock, I.; Wood, S. A test of character: Regulating place-identity in inner-city Melbourne. Urban Stud. 2009, 46, 2595-2615. [CrossRef]

25. Burton, E.; Jenks, M.; Williams, K. The Compact City: A Sustainable Urban Form? Routledge: London, UK, 2003.

26. Llewelin-Davies. Urban Design Compendium; English Partnership and the Housing Corporation: London, UK, 2000.

27. Frumkin, H.; Frank, L.; Jackson, R.J. Urban Sprawl and Public Health: Designing, Planning, and Building for Healthy Communities; Island Press: Washington, DC, USA, 2004.

28. Putnam, R.D. Bowling Alone: The Collapse and Revival of American Community; Simon \& Schuster Paperbacks: New York, NY, USA, 2000.

29. Dovey, K.; Wood, S. Public/private urban interfaces: Type, adaptation, assemblage. J. Urban. Int. Res. Placemaking Urban Sustain. 2015, 8, 1-16. [CrossRef]

30. Bentley, I. Responsive Environments: A Manual for Designers; Routledge: London, UK, 1985.

31. Altman, I. The Environment and Social Behavior: Privacy, Personal Space, Territory, and Crowding; Brooks Cole Publishing Company: Pacific Grove, CA, USA, 1975.

32. Simmel, G. The Sociology of Georg Simmel; Translated, Edited, and with an Introduction by K.H. Wolff; The Free Press: New York, NY, USA, 1950.

33. Iveson, K. Strangers in the cosmopolis. In Cosmopolitan Urbanism; Binnie, J., Holloway, J., Millington, S., Young, C., Eds.; Routledge: London, UK, 2006; pp. 70-86.

34. Mehta, V. The Street: A Quintessential Social Public Space; Routledge: London, UK, 2013.

35. Mehta, V. Look closely and you will see, listen carefully and you will hear: Urban design and social interaction on streets. J. Urban Des. 2009, 14, 29-64. [CrossRef]

36. Marcus, C.C.; Francis, C. People Places: Design Guidelines for Urban Open Space; John Wiley \& Sons: New York, NY, USA, 1998.

37. Dornbusch, D.M.; Gelb, P.M. On the use of parks and plazas. In Human Response to Tall Buildings; Conway, D.J., Ed.; John Wiley \& Sons: New York, NY, USA, 1977; pp. 112-130.

38. Joardar, S.; Neill, J. The subtle differences in configuration of small public spaces. Landsc. Archit. 1978, $68,487-491$. 
39. Linday, N. It all comes down to a comfortable place to sit and watch. Landsc. Archit. 1978, 68, $492-497$.

40. Miles, D.C.; Cook, R.S.; Roberts, C.B. Plazas for People; Project for Public Spaces: New York, NY, USA, 1978.

41. Share, L.A.P. Giannini Plaza and Transamerica Park: Effects of their physical characteristics on users' perception and experiences. In New Directions in Environmental Design Research; Rogers, W., Ittelson, W., Eds.; Environmental Design Research Association: Washington, DC, USA, 1978; pp. 127-139.

42. Whyte, W.H. The Social Life of Small Urban Spaces; Conservation Foundation: Washington, DC, USA, 1980.

43. Liebermann, E. People's needs and preferences as the basis of San Francisco's downtown open space plan. In Proceedings of the 8th Conference of the International Association for the Study of People and Their Physical Surroundings, Berlin, Germany, 25-29 July 1984.

44. Banerjee, T.; Loukaitou-Sideris, A. Private Production of Downtown Public Open Space: Experiences of Los Angeles and San Francisco; School of Urban and Regional Planning, University of Southern California: Los Angeles, CA, USA, 1992.

45. Loukaitou-Sideris, A.; Banerjee, T. The negotiated plaza: Design and development of corporate open space in downtown Los Angeles and San Francisco. J. Plan. Educ. Res. 1993, 13, 1-12. [CrossRef]

46. Appleyard, D. Livable Streets, Protected Neighborhoods; University of California Press: Berkeley, CA, USA, 1981.

47. Eubank-Ahrens, B. The impact of "woonerven" on children's behavior. Children's Environ. Q. 1984, 1, 39-45.

48. Eubank-Ahrens, B. A closer look at the users of woonerven. In Public Streets for Public Use; Moudon, A.V., Ed.; Van Nostrand Reinhold: New York, NY, USA, 1987; pp. 63-79.

49. Skjœveland, O. Effects of street parks on social interactions among neighbors: A place perspective. J. Archit. Plan. Res. 2001, 18, 131-147.

50. Sullivan, W.C.; Kuo, F.E.; Depooter, S.F. The fruit of urban nature: Vital neighborhood spaces. Environ. Behav. 2004, 36, 678-700. [CrossRef]

51. Jacobs, A.B. Great Streets; MIT Press: Cambridge, MA, USA, 1993.

52. Lang, J. Creating Architectural Theory: The Role of the Behavioral Sciences in Environmental Design; Van Nostrand Reinhold: New York, NY, USA, 1987.

53. Barker, R.G. Ecological Psychology: Concepts and Methods for Studying the Environment of Human Behavior; Stanford University Press: Stanford, CA, USA, 1968.

54. Gehl, J.; Svarre, B. How to Study Public Life; Island Press: Washington, DC, USA, 2013.

55. Studer, R.G. The dynamics of behavior-contingent physical systems. Ekistics 1969, 27, 185-197.

56. Craik, K.H. The environmental dispositions of environmental decision-makers. Ann. Am. Acad. Polit. Soc. Sci. 1970, 389, 87-94. [CrossRef]

57. Michelson, W.M. Behavioral Research Methods in Environmental Design; Dowden Hutchinson and Ross: Stroudsburg, PA, USA, 1975.

58. Appleyard, D.; Lintell, M. The environmental quality of city streets: The residents' viewpoint. J. Am. Inst. Plan. 1972, 38, 84-101. [CrossRef]

59. Gehl, J. Life between Buildings: Using Public Space; Island Press: Washington, DC, USA, 2011.

60. Groat, L.N.; Wang, D. Architectural Research Methods; John Wiley \& Sons: New York, NY, USA, 2013.

61. Joardar, S.D. Emotional and Behavioral Responses of People to Urban Plazas: A Case Study of Downtown Vancouver; University of British Columbia: Vancouver, BC, Canada, 1977.

62. French, S.; Wood, L.; Foster, S.A.; Giles-Corti, B.; Frank, L.; Learnihan, V. Sense of community and its association with the neighborhood built environment. Environ. Behav. 2014, 46, 677-697. [CrossRef]

63. Rohe, W.M.; Gates, L.B. Planning with Neighborhoods; The University of North Carolina Press: Chapel Hill, NC, USA, 1985.

64. Taylor, M. Community, Anarchy and Liberty; Cambridge University Press: Cambridge, UK, 1982.

65. Weidemann, S.; Anderson, J.R. A conceptual framework for residential satisfaction. In Home Environments; Altman, I., Werner, C.M., Eds.; Springer: Berlin, Germany, 1985; pp. 153-182.

66. Cook, P.E. Community Psychology and Community Mental Health: Introductory Readings; Holden-Day: San Francisco, CA, USA, 1970.

67. Mesch, G.S.; Manor, O. Social ties, environmental perception, and local attachment. Environ. Behav. 1998, 30, 504-519. [CrossRef]

68. Troy, P. Australian urban research and planning. Urban Policy Res. 2013, 31, 134-149. [CrossRef] 
69. Timms, P. Australia's Quarter Acre: The Story of the Ordinary Suburban Garden; Melbourne University Press: Melbourne, Australia, 2006.

70. Banham, R. Architecture of the Well-Tempered Environment; University of Chicago Press: Chicago, IL, USA, 1984.

71. Schroeder, F.E. Front Yard America: The Evolution and Meanings of a Vernacular Domestic Landscape; Bowling Green State University Popular Press: Bowling Green, OH, USA, 1993.

72. Pollan, M. Second Nature: A Gardener's Education; Grove Press: New York, NY, USA, 2007.

73. Daniels, T.; Lapping, M. Land preservation: An essential ingredient in smart growth. J. Plan. Lit. 2005, 19, 316-329. [CrossRef]

74. Brower, S.N. Territory in urban settings. In Environment and Culture; Springer: Berlin, Germany, 1980; pp. 179-207.

75. Hall, E.T. The Hidden Dimension; Doubleday: Garden City, NY, USA, 1966.

76. Sommer, R. Personal Space: The Behavioral Basis of Design; Prentice-hall: Englewood Cliffs, NJ, USA, 1969.

77. Jacob, P. A dialectic of personal and communal aesthetics: Paradigms of yard ornamentation in northeastern America. J. Popular Cult. 1992, 26, 91-105. [CrossRef]

78. Zmyslony, J.; Gagnon, D. Residential management of urban front-yard landscape: A random process? Landsc. Urban Plan. 1998, 40, 295-307. [CrossRef]

79. Jurkow, G. Rediscovering and Recovering the Front Yard: A Study of Garden Yard Meaning and Owner Attitudes. Master's Thesis, University of Manitoba, Ottawa, ON, Canada, 2000.

80. Jim, C. Trees and landscape of a suburban residential neighbourhood in Hong Kong. Landsc. Urban Plan. 1993, 23, 119-143. [CrossRef]

81. Nisbet, R.A.; Perrin, R.G.; Page, C.H. The Social Bond; Alfred A. Knopf: New York, NY, USA, 1977.

82. McMillan, D.W.; Chavis, D.M. Sense of community: A definition and theory. J. Community Psychol. 1986, 14, 6-23. [CrossRef]

83. Kohn, M. Brave New Neighborhoods: The Privatization of Public Space; Routledge: London, UK, 2004.

84. Newman, O. Defensible Space; Macmillan: New York, NY, USA, 1972.

85. Newman, O. Architectural Design for Crime Prevention; National Institute of Law Enforcement and Criminal Justice: Washington, DC, USA, 1973.

86. Chua, B.H. A practicable concept of community in high-rise, high density housing environment. Singapore Archit. 1995, 189, 95.

87. Capon, A.G. The way we live in our cities. Med. J. Aust. 2007, 187, 658-660. [PubMed]

88. McMillan, D.W. Sense of community. J. Community Psychol. 1996, 24, 315-325. [CrossRef]

89. McMillan, D.W. Sense of community, a theory not a value: A response to Nowell and Boyd. J. Community Psychol. 2011, 39, 507-519. [CrossRef]

90. Doolittle, R.J.; MacDonald, D. Communication and a sense of community in a metropolitan neighborhood: A factor analytic examination. Commun. Q. 1978, 26, 2-7. [CrossRef]

91. Tropman, J.E. Critical dimensions of community structure: A reexamination of the Hadden-Borgatta findings. Urban Affairs Q. 1969, 5, 215-232. [CrossRef]

92. Backman, C.W.; Secord, P.F. The effect of perceived liking on interpersonal attraction. Hum. Relations 1959, 12, 379-384. [CrossRef]

93. Aronson, E.; Mills, J. The effect of severity of initiation on liking for a group. J. Abnorm. Soc. Psychol. 1959, 59, 177. [CrossRef]

94. Buss, A.H.; Portnoy, N.W. Pain tolerance and group identification. J. Personal. Soc. Psychol. 1967, 6, 106. [CrossRef]

95. Davison, G.; Rowden, E. “There's something about Subi": Defending and creating neighbourhood character in Perth, Australia. J. Urban Des. 2012, 17, 189-212. [CrossRef]

96. Kearns, A.; Forrest, R. Social cohesion and multilevel urban governance. Urban Stud. 2000, 37, 995-1017. [CrossRef]

97. Nash, V.; Christie, I. Making Sense of Community; Institute for Public Policy Research (IPPR): London, UK, 2003.

98. Dempsey, N.; Bramley, G.; Power, S.; Brown, C. The social dimension of sustainable development: Defining urban social sustainability. Sustain. Dev. 2011, 19, 289-300. [CrossRef]

99. Rappaport, J. Community Psychology: Values, Research, and Action; Holt, Rinehart and Winston: New York, NY, USA, 1977. 
100. Allan, T.K.; Allan, K.H. Sensitivity training for community leaders. In Proceedings of the Annual Convention of the American Psychological Association; American Psychological Association: Washington, DC, USA, 1971.

101. Festinger, L. Informal social communication. Psychol. Rev. 1950, 57, 271-282. [CrossRef] [PubMed]

102. Sherif, M.; White, B.J.; Harvey, O. Status in experimentally produced groups. Am. J. Sociol. 1955, 60, 370-379. [CrossRef]

103. Wilson, W.; Miller, N. Shifts in evaluations of participants following intergroup competition. J. Abnorm. Soc. Psychol. 1961, 63, 428. [CrossRef] [PubMed]

104. Dear, M. Understanding and overcoming the nimby syndrome. J. Am. Plan. Assoc. 1992, 58, $288-300$. [CrossRef]

105. Chavis, D.M.; Hogge, J.H.; McMillan, D.W.; Wandersman, A. Sense of community through Brunswik's lens: A first look. J. Community Psychol. 1986, 14, 24-40. [CrossRef]

106. Holtzman, G. Community by design, by the people: Social approach to designing and planning cohousing and ecovillage communities. J. Green Build. 2014, 9, 60-82. [CrossRef]

107. Whyte, W.H. Securing Open Space for Urban America: Conservation Easements; Urban Land Institute: Washington, DC, USA, 1959.

108. Gehl, J. “Soft edges" in residential streets. Scand. Hous. Plan. Res. 1986, 3, 89-102. [CrossRef]

109. Bay, J.H. Towards a fourth ecology: Social and environmental sustainability with architecture and urban design. J. Green Build. 2010, 5, 176-197. [CrossRef]

110. Carmona, M. Controlling urban design—part 1: A possible renaissance? J. Urban Des. 1996, 1, 47-73. [CrossRef]

111. Hass-Klau, C.; Crampton, G.; Dowland, C.; Nold, I. Streets as Living Space: Helping Public Places Play Their Proper Role; Landor Publishing: London, UK, 1999.

112. Stedman, R.C. Sense of place as an indicator of community sustainability. For. Chron. 1999, 75, 765-770. [CrossRef]

113. Bay, J.H.P.; Lehmann, S. (Eds.) Growing Compact: Urban Form, Density and Sustainability; Taylor \& Francis: Oxford, UK, 2017.

114. Lynch, K. The Image of the City; MIT Press: Cambridge, MA, USA, 1960; Volume 11.

115. Yin, R.K. Validity and generalization in future case study evaluations. Evaluation 2013, 19, 321-332. [CrossRef]

116. Drever, E. Using Semi-Structured Interviews in Small-Scale Research: A Teacher's Guide; Scottish Council for Research in Education: Glasgow, UK, 1995.

117. Harrell, M.C.; Bradley, M.A. Data Collection Methods. Semi-Structured Interviews and Focus Groups; Rand National Defense Research Institute: Santa Monica, CA, USA, 2009.

118. Howe, A.; Glass, G.; Curtis, C. Retrofitting TOD and managing the impacts: The case of Subi Centro. In Transit Oriented Development: Making It Happen; Curtis, C., Renne, J.L., Bertolini, L., Eds.; Ashgate: Farnham, UK, 2009; pp. 65-73.

119. Spillman, K. Identity Prized: A History of Subiaco; University of Western Australia Press for the City of Subiaco: Perth, Australia, 1985.

120. Spillman, K. Tales of a Singular City: Subiaco since the 1970s; City of Subiaco: Perth, Australia, 2006.

121. Australian Bureau of Statistics (ABS). Regional Population Growth, Australia, 2016-17; Cat. \# 3218.0; ABS: Canberra, Australia, 2018.

122. Australian Bureau of Statistics (ABS). Wage and Salary Earner Statistics for Small Areas, Time Series, 2003-04 to 2008-09; Cat. \# 5673.0.55.003; ABS: Canberra, Australia, 2011.

123. City of Subiaco Community Profile: Individual Income, 2016. Available online: https://profile.id.com.au/ subiaco/individual-income (accessed on 29 April 2018).

124. Strasburger, H.; Rentschler, I.; Jüttner, M. Peripheral vision and pattern recognition: A review. J. Vis. 2011, 11, 13. [CrossRef] [PubMed]

125. Crowhurst Lennard, S.; Lennard, H. Livable Cities Observed: A Source Book of Images and Ideas for City Officials, Community Leaders, Architects, Planners and All Others Committed to Making Their Cities Liveable; Gondolier Press: Carmel, CA, USA, 1995.

126. Scheer, B.C. The Evolution of Urban Form: Typology for Planners and Architects; Routledge: London, UK, 2017.

127. Caniggia, G.; Maffei, G.L. Architectural Composition and Building Typology: Interpreting Basic Building; Alinea Editrice: Florence, Italy, 2001. 
128. Moudon, A.V. The role of typomorphological studies in environmental design research. In Changing Paradigms; Hardie, G., Moore, R., Sanoff, H., Eds.; University of Washington: Seattle, WA, USA, 1989; pp. 41-48.

129. Peterson, J.A.; Martens, R. Success and residential affiliation as determinants of team cohesiveness. Res. Quart. 1972, 43, 62-76.

130. Polzer, J.T.; Neale, M.A.; Glenn, P.O. The effects of relationships and justification in an interdependent allocation task. Group Decis. Negot. 1993, 2, 135-148. [CrossRef]

131. Moustafa, Y.M. Design and neighborhood sense of community: An integrative and cross-culturally valid theoretical framework. Int. J. Archit. Res. 2009, 3, 71-91.

132. Pacione, $\mathrm{M}$. The retirement village as a residential environment for the third age-The example of Firhall, Scotland. Scott. Geogr. J. 2012, 128, 148-168. [CrossRef]

133. Abass, Z.; Tucker, R. White picket fences \& other features of the suburban physical environment: Correlates of neighbourhood attachment in 3 Australian low-density suburbs. Landsc. Urban Plan. 2018, 170, 231-240.

134. Kim, J.; Kaplan, R. Physical and psychological factors in sense of community: New urbanist Kentlands and nearby Orchard Village. Environ. Behav. 2004, 36, 313-340. [CrossRef]

135. Talen, E. Sense of community and neighbourhood form: An assessment of the social doctrine of new urbanism. Urban Stud. 1999, 36, 1361-1379. [CrossRef]

136. Abu-Ghazzeh, T.M. Housing layout, social interaction, and the place of contact in Abu-Nuseir, Jordan. J. Environ. Psychol. 1999, 19, 41-73. [CrossRef]

137. Patricios, N.N. The neighborhood concept: A retrospective of physical design and social interaction. J. Archit. Plan. Res. 2002, 70-90.

138. Francis, J.; Giles-Corti, B.; Wood, L.; Knuiman, M. Creating sense of community: The role of public space. J. Environ. Psychol. 2012, 32, 401-409. [CrossRef]

139. Soja, E.W. Seeking Spatial Justice; University of Minnesota Press: Minneapolis, MN, USA, 2010.

140. Florida, R. The Rise of the Creative Class: And How It's Transforming Work, Leisure, Community and Everyday Life; Basic Books: New York, NY, USA, 2004.

141. Florida, R. The Flight of the Creative Class; Harper Business: New York, NY, USA, 2005.

142. Florida, R. Who's Your City?: How the Creative Economy Is Making Where to Live the Most Important Decision of Your Life; Vintage Canada: Toronto, ON, Canada, 2010.

143. Grodach, C.; Loukaitou-Sideris, A. Cultural development strategies and urban revitalization: A survey of US cities. Int. J. Cult. Policy 2007, 13, 349-370. [CrossRef]

144. Gilbert, A. The roots of Australian anti-suburbanism. In Australian Cultural History; Goldberg, S.L., Smith, F.B., Eds.; Cambridge University Press in Association with the Australian Academy of the Humanities: Cambridge, UK; Melbourne, Australia, 1988; pp. 33-39.

145. Madanipour, A. Public and Private Spaces of the City; Routledge: London, UK, 2003.

146. City of Subiaco Town Planning Controls and Policies, 2018. Available online: http:/ /www.subiaco.wa.gov.au/ Planning-and-development/Town-planning-controls-and-policies (accessed on 29 April 2018).

147. Department of Planning. R-Codes: Residential Design Codes of Western Australia. Explanatory Guidelines; State of Western Australia: Perth, Australia, 2015.

148. Lawson, B. Language of Space; Routledge: London, UK, 2007.

149. Ching, F.D. Architecture: Form, Space, and Order; John Wiley \& Sons: New York, NY, USA, 2014.

150. Arendt, H. The Human Condition; University of Chicago Press: Chicago, IL, USA, 2013.

(C) 2018 by the authors. Licensee MDPI, Basel, Switzerland. This article is an open access article distributed under the terms and conditions of the Creative Commons Attribution (CC BY) license (http://creativecommons.org/licenses/by/4.0/). 